\title{
The Efficacy of High-flow Oxygen Versus Conventional Oxygen for Asthma Control: A Meta-analysis of Randomized Controlled Studies
}

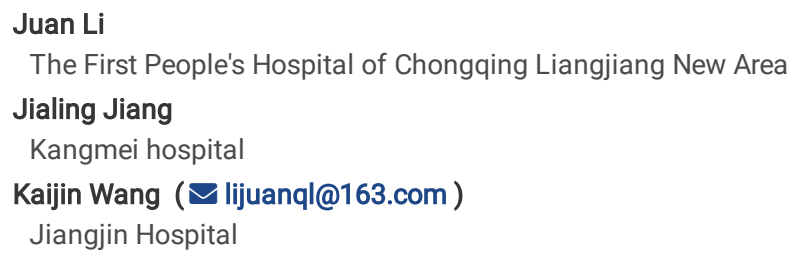

Research article

Keywords: high-flow oxygen, conventional oxygen, asthma, randomized controlled trials

Posted Date: July 8th, 2021

DOI: https://doi.org/10.21203/rs.3.rs-674694/v1

License: (c) (i) This work is licensed under a Creative Commons Attribution 4.0 International License. Read Full License 


\section{Abstract}

Introduction: The efficacy of high-flow oxygen versus conventional oxygen therapy for asthma control remains controversial. We conduct a systematic review and meta-analysis to explore the influence of high-flow oxygen versus conventional oxygen therapy on asthma control.

Methods: We have searched PubMed, EMbase, Web of science, EBSCO, and Cochrane library databases through May 2021 for randomized controlled trials (RCTs) assessing the efficacy of high-flow oxygen versus conventional oxygen therapy for asthma control. This meta-analysis is performed using the randomeffect model.

Results: Four RCTs are included in the meta-analysis. Overall, compared with conventional oxygen therapy for asthma, high-flow oxygen is associated with significantly lower dyspnea score $(\mathrm{SMD}=-0.63 ; 95 \% \mathrm{Cl}=-1.08$ to $-0.17 ; \mathrm{P}=0.008)$, but reveals no remarkable influence on $\mathrm{PaCO} 2(\mathrm{SMD}=0.28 ; 95 \% \mathrm{Cl}=-0.22$ to $0.77 ; \mathrm{P}=0.28), \mathrm{PaO} 2(\mathrm{SMD}=0.44 ; 95 \% \mathrm{Cl}=-1.34$ to $2.22 ; \mathrm{P}=0.63)$, intubation $(\mathrm{OR}=1.09 ; 95 \% \mathrm{Cl}=0.15$ to $8.21 ; \mathrm{P}=0.93)$ or hospital length of stay $(\mathrm{SMD}=-0.07 ; 95 \%$ $\mathrm{Cl}=-0.41$ to $0.27 ; \mathrm{P}=0.67)$.

Conclusions: High-flow oxygen may benefit to reduce dyspnea score than conventional oxygen therapy for asthma.

\section{Introduction}

Asthma, a chronic inflammatory airway disease has the features of airway hyperresponsiveness and reversible airflow obstruction [1-5]. It has become one of the most common airway diseases in both children and adults [6]. It is estimated that the incidence of childhood asthma is $10 \%$ to $13 \%$, which its incidence of adults is lower at 4\% [7-9]. The exacerbation of asthma results in an acute obstruction of expiratory airflow due to airway inflammation, bronchospasm, and hypersecretion, which needs the increased work of breathing $[10,11]$. If emergent and effective treatment is conducted for asthma exacerbation, the respiratory muscles may fatigue, accompanied by hypercapnia, severe hypoxemia, and consequently respiratory failure [12].

The Global Initiative for Asthma (GINA) guideline recommends early administration of supplemental oxygen and medications such as nebulized bronchodilators and systemic corticosteroid for the management of acute severe asthma [6]. The administration approaches of oxygen mainly include nasal cannula and nonrebreather mask which are promising for chronic obstructive pulmonary disease (COPD), but shows limited success for acute severe asthma [13]. High-flow oxygen therapy is the oxygen-delivering method of inspired fraction (FiO2) up to 1.0 via a purposely made high-flow nasal cannula across a range of flows from 2 to $60 \mathrm{~L} / \mathrm{min}$. It also provides positive airway pressure and decreases rebreathing from anatomic dead space, which help reduce respiratory effort $[14,15]$. Many studies reported the effectiveness of high-flow oxygen therapy all-cause hypoxemic respiratory failure and cardiogenic pulmonary edema $[16,17]$.

Current evidence is insufficient for routine clinical use of high-flow oxygen therapy for asthmatic patients. Recently, several studies have investigated the efficacy of high-flow oxygen versus conventional oxygen therapy for these patients, but the results are conflicting $[12,18,19]$. This systematic review and meta-analysis of RCTs aims to assess the efficacy of high-flow oxygen versus conventional oxygen therapy in asthmatic patients.

\section{Materials And Methods}

This systematic review and meta-analysis are performed based on the guidance of the Preferred Reporting Items for Systematic Reviews and Meta-analysis statement and Cochrane Handbook for Systematic Reviews of Interventions [20-22]. No ethical approval and patient consent are required because all analyses are based on previous published studies.

\section{Literature search and selection criteria}

We have systematically searched several databases including PubMed, EMbase, Web of science, EBSCO, and the Cochrane library from inception to May 2021 with the following keywords: "high-flow oxygen" AND "asthma". The reference lists of retrieved studies and relevant reviews are also hand-searched and the process above is performed repeatedly in order to include additional eligible studies.

The inclusion criteria are presented as follows: (1) study design is RCT, (2) patients are diagnosed with asthma, and (3) intervention treatments are high-flow oxygen versus conventional oxygen therapy.

\section{Data extraction and outcome measures}

Some baseline information is extracted from the original studies, and they include first author, number of patients, age, female, medial history of asthma and detail methods in two groups. Data are extracted independently by two investigators, and discrepancies are resolved by consensus. We have contacted the corresponding author to obtain the data when necessary.

The primary outcome is dyspnea score. Secondary outcomes include PaCO2, PaO2, intubation, and hospital length of stay.

\section{Quality assessment in individual studies}

The methodological quality of each RCT is assessed by the Jadad Scale which consists of three evaluation elements: randomization (0-2 points), blinding (0-2 points), dropouts and withdrawals (0-1 points) [23]. One point would be allocated to each element if they have been conducted and mentioned appropriately in the original article. The score of Jadad Scale varies from 0 to 5 points. An article with Jadad score $\leq 2$ is considered to be of low quality. The study is thought to be of high quality if Jadad score $\geq 3[22,24]$. 


\section{Statistical analysis}

We assess standard mean difference (SMD) with 95\% confidence intervals (Cls) for continuous outcomes (dyspnea score, PaCO2, PaO2 and hospital length of stay) and odd ratio (OR) with $95 \% \mathrm{Cl}$ for dichotomous outcome (intubation). Heterogeneity is evaluated using the $\mathrm{I}^{2}$ statistic, and $\mathrm{I}^{2}>50 \%$ indicates significant heterogeneity [25]. The random-effects model is used for all meta-analysis. We search for potential sources of heterogeneity for significant heterogeneity. Sensitivity analysis is performed to detect the influence of a single study on the overall estimate via omitting one study in turn or performing the subgroup analysis. Owing to the limited number $(<10)$ of included studies, publication bias is not assessed. Results are considered as statistically significant for $P<0.05$. All statistical analyses are performed using Review Manager Version 5.3 (The Cochrane Collaboration, Software Update, Oxford, UK).

\section{Results}

\section{Literature search, study characteristics and quality assessment}

Figure 1 shows the detail flowchart of the search and selection results. 152 potentially relevant articles are identified initially. Finally, four RCTs are included in the meta-analysis $[12,18,19,26]$.

The baseline characteristics of four included RCTs are shown in Table 1. These studies are published between 2018 and 2021 , and the total sample size is 175. High-flow oxygen ranges from 2 to $60 \mathrm{~L} / \mathrm{min}$. one RCT involves children with asthma [26], while the other three RCTs involve adult patients [12, 18, 19].

Two studies report dyspnea score [12, 19], two studies report dyspnea score PaCO2, PaO2 and intubation [12, 18], and three studies report dyspnea score hospital length of stay $[12,18,26]$. Jadad scores of the four included studies vary from 3 to 4 , and all four studies have high-quality based on the quality assessment.

\section{Primary outcome: dyspnea score}

The random-effect model is used for the analysis of primary outcome. The results find that compared to conventional oxygen therapy for asthma, high-flow oxygen is associated with significantly lower dyspnea score $(S M D=-0.63 ; 95 \% \mathrm{Cl}=-1.08$ to $-0.17 ; \mathrm{P}=0.008)$, with no heterogeneity among the studies $\left(\mathrm{I}^{2}=0 \%\right.$, heterogeneity $\mathrm{P}=0.87$, Figure 2 ).

\section{Sensitivity analysis}

There is no heterogeneity for dyspnea score, and thus we do not perform sensitivity analysis by omitting one study in each turn to detect the source of heterogeneity.

\section{Secondary outcomes}

In comparison with conventional oxygen therapy for asthma, high-flow oxygen shows no obvious impact on $\mathrm{PaCO} 2(\mathrm{SMD}=0.28 ; 95 \% \mathrm{Cl}=-0.22$ to 0.77 ; $\mathrm{P}=0.28$; Figure 3), $\mathrm{PaO} 2$ ( $\mathrm{SMD}=0.44 ; 95 \% \mathrm{Cl}=-1.34$ to $2.22 ; \mathrm{P}=0.63$; Figure 4$)$, intubation $(\mathrm{OR}=1.09 ; 95 \% \mathrm{Cl}=0.15$ to $8.21 ; \mathrm{P}=0.93 ;$ Figure 5$)$ or hospital length of stay (SMD $=-0.07 ; 95 \% \mathrm{Cl}=-0.41$ to $0.27 ; \mathrm{P}=0.67$; Figure 6$)$.

\section{Table 1 Characteristics of included studies}




\begin{tabular}{|c|c|c|c|c|c|c|c|c|c|c|c|c|}
\hline \multirow[t]{2}{*}{ NO. } & \multirow[t]{2}{*}{ Author } & \multicolumn{5}{|c|}{ High flow group } & \multicolumn{5}{|c|}{ Control group } & \multirow[t]{2}{*}{$\begin{array}{l}\text { Jada } \\
\text { score }\end{array}$} \\
\hline & & Number & Age (years) & $\begin{array}{l}\text { Female } \\
\text { (n) }\end{array}$ & $\begin{array}{l}\text { Duration } \\
\text { of } \\
\text { asthma } \\
\text { (year) }\end{array}$ & Methods & Number & $\begin{array}{l}\text { Age } \\
\text { (years) }\end{array}$ & $\begin{array}{l}\text { Female } \\
\text { (n) }\end{array}$ & $\begin{array}{l}\text { Duration } \\
\text { of } \\
\text { asthma } \\
\text { (year) }\end{array}$ & Methods & \\
\hline 1 & $\begin{array}{l}\text { Ruangsomboon } \\
2021\end{array}$ & 19 & $63.7 \pm 16.9$ & 16 & - & $\begin{array}{l}35 \mathrm{~L} / \mathrm{min} \text {, } \\
\text { adjusted } \\
\text { from } 30 \text { to } \\
60 \mathrm{~L} / \mathrm{min} \\
\text { according } \\
\text { to the } \\
\text { participant's } \\
\text { level of } \\
\text { comfort }\end{array}$ & 18 & $63.2 \pm 21.8$ & 15 & - & $\begin{array}{l}\text { standard } \\
\text { oxygen } \\
\text { nasal } \\
\text { cannula }\end{array}$ & 3 \\
\hline 2 & Geng 2020 & 16 & $43.3 \pm 10.6$ & 10 & $\begin{array}{l}6.38 \pm \\
1.28\end{array}$ & $\begin{array}{l}\text { initial gas } \\
\text { flow of } 30- \\
40 \text { L/min, to } \\
\text { maintain } \\
\text { pulse } \\
\text { oxygen } \\
\text { saturation } \\
\text { at } 92 \%- \\
96 \%\end{array}$ & 20 & $37.5 \pm 8.4$ & 12 & $\begin{array}{l}5.95 \pm \\
1.36\end{array}$ & $\begin{array}{l}\text { standard } \\
\text { oxygen } \\
\text { nasal } \\
\text { cannula }\end{array}$ & 4 \\
\hline 3 & Raeisi 2019 & 20 & $50.75 \pm 10.7$ & 15 & $5.3 \pm 2.7$ & $\begin{array}{l}\text { flow } \\
\text { range 15- } \\
35 \mathrm{~L} / \mathrm{min}\end{array}$ & 20 & $44.4 \pm 11.6$ & 13 & $6.4 \pm 3.4$ & $\begin{array}{l}\text { standard } \\
\text { oxygen } \\
\text { nasal } \\
\text { cannula }\end{array}$ & 4 \\
\hline 4 & Ballestero 2018 & 30 & $\begin{array}{l}3.0(1.7- \\
6.0), \\
\text { median } \\
\text { (range) }\end{array}$ & 15 & - & $\begin{array}{l}\text { flow range } \\
2-25 \mathrm{~L} / \mathrm{min}\end{array}$ & 32 & $\begin{array}{l}3.0(2.0- \\
6.0)\end{array}$ & 14 & - & $\begin{array}{l}\text { standard } \\
\text { oxygen } \\
\text { nasal } \\
\text { cannula }\end{array}$ & 3 \\
\hline
\end{tabular}

\section{Discussion}

Several studies demonstrated the benefit of high-flow oxygen therapy in decreasing the arterial partial pressure of carbon dioxide (PaCO2) in patients with hypercapnic respiratory failure secondary to COPD [27-29]. In patients with severe asthma, high-flow oxygen therapy also showed favorable benefit to decrease respiratory rate and increase their expiratory time which thereby help decrease dynamic hyperinflation. In addition, heated and humidified air could increase the comfort and reduce bronchoconstriction induced by cold air [12].

Our meta-analysis included four RCTs and 175 patients, and the results revealed that high-flow oxygen therapy was associated with significantly lower dyspnea score than conventional oxygen therapy for asthma, but $\mathrm{PaCO} 2, \mathrm{PaO} 2$, intubation and hospital length of stay were found to be similar between two groups. In pediatric patients with acute severe asthma, high-flow oxygen therapy was approved to improve clinical severity compared with both conventional oxygen therapy [26,30]. Its benefits to decrease $\mathrm{PaCO} 2$ and an increase in the $\mathrm{pH}$ level were also confirmed in children and adolescents [31].

In Fig. 3, only adults patients were included for the meta-analysis of PaCO2 after pooling the results of two RCTs [12, 18]. These suggested that high-flow oxygen therapy may provide better efficacy to decrease $\mathrm{PaCO} 2$ and improve clinical severity in pediatric patients than that in adult patients. Regarding the sensitivity analysis, although there is no significant heterogeneity, several factors may produce some bias. Firstly, children and adult patients are both included in this meta-analysis, which may affect the evaluation of efficacy such as the decrease in PaCO2. Secondly, the flow range and detail methods of high-flow oxygen therapy were various among the four RCTs. Thirdly, the severity of asthma were different, which may affect the efficacy evaluation of high-flow oxygen therapy.

Several limitations exist in this meta-analysis. Firstly, our analysis is based on only four RCTs, and more RCTs with large sample size should be conducted to explore this issue. Next, although there is no significant heterogeneity, different flow range and severity of asthma may lead to some bias. Finally, it is not feasible to perform the analysis of some outcomes such as modified Borg scale and respiratory rate.

\section{Conclusion}

High-flow oxygen therapy may benefit to decrease dyspnea score than conventional oxygen therapy in asthmatic patients.

\section{Abbreviations}

randomized controlled trials: RCTs

mean differences: MDs

confidence intervals: Cls

risk ratios: RRs 


\section{Declarations}

\section{Ethical Approval and Consent to participate}

Not applicable.

\section{Consent for publication}

Not applicable.

\section{Availability of supporting data}

Not applicable.

Competing interests

The authors declare no conflict of interest.

\section{Funding}

Not applicable.

\section{Authors' contributions}

Juan Li conducted the design, Jialing Jiang conducted the study planning, data analysis and data interpretation, Kaijin Wang wrote and revised the article. All authors read and approved the final manuscript.

\section{Acknowledgements}

None.

\section{References}

\section{References}

1. Papi A, Brightling C, Pedersen SE, Reddel HK, Asthma. Lancet. 2018;391(10122):783-800.

2. Barnes PJ, Cellular and molecular mechanisms of asthma and COPD, Clinical science (London, England: 1979) 131(13) (2017) 1541-1558.

3. Padem N, Saltoun C, Classification of asthma, Allergy and asthma proceedings 40(6) (2019) 385-388.

4. Fehrenbach $H$, Wagner C, Wegmann M. Airway remodeling in asthma: what really matters. Cell tissue research. 2017;367(3):551-69.

5. Ramsahai JM, Hansbro PM, Wark PAB. Mechanisms and Management of Asthma Exacerbations. Am J Respir Crit Care Med. 2019;199(4):423-32.

6. Boulet L-P, Reddel HK, Bateman E, Pedersen S, FitzGerald JM. P.M.J.E.R.J. O'Byrne, The global initiative for asthma (GINA): 25 years later, $54(2)$ (2019).

7. Teeratakulpisarn J, Pairojkul S, Heng S. Survey of the prevalence of asthma, allergic rhinitis and eczema in schoolchildren from Khon Kaen, Northeast Thailand. an ISAAC study. International Study of Asthma and Allergies in Childhood. Asian Pacific journal of allergy immunology. 2000;18(4):187-94.

8. Boonsawat W, Charoenphan P, Kiatboonsri S, Wongtim S, Viriyachaiyo V, Pothirat C, Thanomsieng N. Survey of asthma control in Thailand Respirology (Carlton Vic). 2004;9(3):373-8.

9. Boonsawat W, Thompson PJ, Zaeoui U, Samosorn C, Acar G, Faruqi R, Poonnoi P. Survey of asthma management in Thailand - the asthma insight and management study. Asian Pacific journal of allergy immunology. 2015;33(1):14-20.

10. Castillo JR, Peters SP, Busse WW, Asthma Exacerbations: Pathogenesis, Prevention, and Treatment, The journal of allergy and clinical immunology. In practice 5(4) (2017) 918-927.

11. Peters MC, Mauger D, Ross KR, Phillips B, Gaston B, Cardet JC, Israel E, Levy BD, Phipatanakul W, Jarjour NN, Castro M, Wenzel SE, Hastie A, Moore W, Bleecker E, Fahy JV. L.C. Denlinger, Evidence for Exacerbation-Prone Asthma and Predictive Biomarkers of Exacerbation Frequency. Am J Respir Crit Care Med. 2020;202(7):973-82.

12. Ruangsomboon O, Limsuwat C, Praphruetkit N, Monsomboon A, Chakorn T. Nasal High-flow Oxygen Versus Conventional Oxygen Therapy for Acute Severe Asthma Patients: A Pilot Randomized Controlled Trial, Academic emergency medicine: official. journal of the Society for Academic Emergency Medicine. 2021;28(5):530-41.

13. Ram FS, Picot J, Lightowler J. J.A.J.C.d.o.s.r. Wedzicha, Non-invasive positive pressure ventilation for treatment of respiratory failure due to exacerbations of chronic obstructive pulmonary disease, (3) (2004).

14. Roca O, Riera J, Torres F, Masclans JR. High-flow oxygen therapy in acute respiratory failure. Respiratory care. 2010;55(4):408-13.

15. Gotera C, Díaz Lobato S, Pinto T, Winck JC. Clinical evidence on high flow oxygen therapy and active humidification in adults. Revista Portuguesa Pneumol. 2013;19(5):217-27.

16. Rittayamai N, Tscheikuna J, Praphruetkit N, Kijpinyochai S. Use of High-Flow Nasal Cannula for Acute Dyspnea and Hypoxemia in the Emergency Department. Respiratory care. 2015;60(10):1377-82.

17. Ruangsomboon O, Dorongthom T, Chakorn T, Monsomboon A, Praphruetkit N, Limsuwat C, Surabenjawong U, Riyapan S, Nakornchai T, Chaisirin W. HighFlow Nasal Cannula Versus Conventional Oxygen Therapy in Relieving Dyspnea in Emergency Palliative Patients With Do-Not-Intubate Status: A Randomized Crossover Study. Ann Emerg Med. 2020;75(5):615-26. 
18. Geng W, Batu W, You S, Tong Z, He H. High-Flow Nasal Cannula: A Promising Oxygen Therapy for Patients with Severe Bronchial Asthma Complicated with Respiratory Failure, Canadian respiratory journal 2020 (2020) 2301712.

19. Raeisi S, Fakharian A, Ghorbani F, Jamaati HR, Mirenayat MS. Value and Safety of High Flow Oxygenation in the Treatment of Inpatient Asthma: A Randomized, Double-blind, Pilot Study. Iran J Allergy Asthma Immunol. 2019;18(6):615-23.

20. Moher D, Liberati A, Tetzlaff J, Altman DG, Group P. Preferred reporting items for systematic reviews and meta-analyses: the PRISMA statement. Bmj. 2009;339:b2535.

21. HigginsJPT G, Cochrane handbook for systematic reviews of interventions version 5.1. 0 [updated March 2011], The cochrane collaboration (2011).

22. Zhao J, Huang W, Zhang S, Xu J, Xue W, He B, Zhang Y, Efficacy of Glutathione for Patients With Cystic Fibrosis: A Meta-analysis of RandomizedControlled Studies, American Journal of Rhinology \& Allergy (2019) 1945892419878315.

23. Jadad AR, Moore RA, Carroll D, Jenkinson C, Reynolds DJM, Gavaghan DJ, McQuay HJ. Assessing the quality of reports of randomized clinical trials: Is blinding necessary? Control Clin Trials. 1996;17(1):1-12.

24. Kjaergard LL, Villumsen J, Gluud C. Reported Methodologic Quality and Discrepancies between Large and Small Randomized Trials in Meta-Analyses. Ann Intern Med. 2001;135(11):982-9.

25. Higgins JP, Thompson SG. Quantifying heterogeneity in a meta-analysis. Statistics in medicine. 2002;21(11):1539-58.

26. Ballestero Y, De Pedro J, Portillo N, Martinez-Mugica O, Arana-Arri E, Benito J. Pilot Clinical Trial of High-Flow Oxygen Therapy in Children with Asthma in the Emergency Service. J Pediatr. 2018;194:204-10.e3.

27. Lee HW, Choi SM, Lee J, Park YS, Lee CH, Yoo CG, Kim YW, Han SK, Lee SM. Reduction of PaCO(2) by high-flow nasal cannula in acute hypercapnic respiratory failure patients receiving conventional oxygen therapy. Acute critical care. 2019;34(3):202-11.

28. Pisani L, Betti S, Biglia C, Fasano L, Catalanotti V, Prediletto I, Comellini V, Bacchi-Reggiani L, Fers SN. Effects of high-flow nasal cannula in patients with persistent hypercapnia after an acute COPD exacerbation: a prospective pilot study. BMC pulmonary medicine. 2020;20(1):12.

29. Rittayamai N, Phuangchoei P, Tscheikuna J, Praphruetkit N, Brochard L. Effects of high-flow nasal cannula and non-invasive ventilation on inspiratory effort in hypercapnic patients with chronic obstructive pulmonary disease: a preliminary study. Ann Intensiv Care. 2019;9(1):122.

30. Baudin F, Buisson A, Vanel B, Massenavette B, Pouyau R, Javouhey E. Nasal high flow in management of children with status asthmaticus: a retrospective observational study. Ann Intensiv Care. 2017;7(1):55.

31. David MMC, Gomes ELDFD, Cavassin CLF, Luiz JG, De Andrade MC, Costa D, Clinical impact of the High Flow Nasal Cannula in the treatment of asthma crisis in children and adolescents. A pilot study, Eur Respiratory Soc, 2019.

\section{Figures}




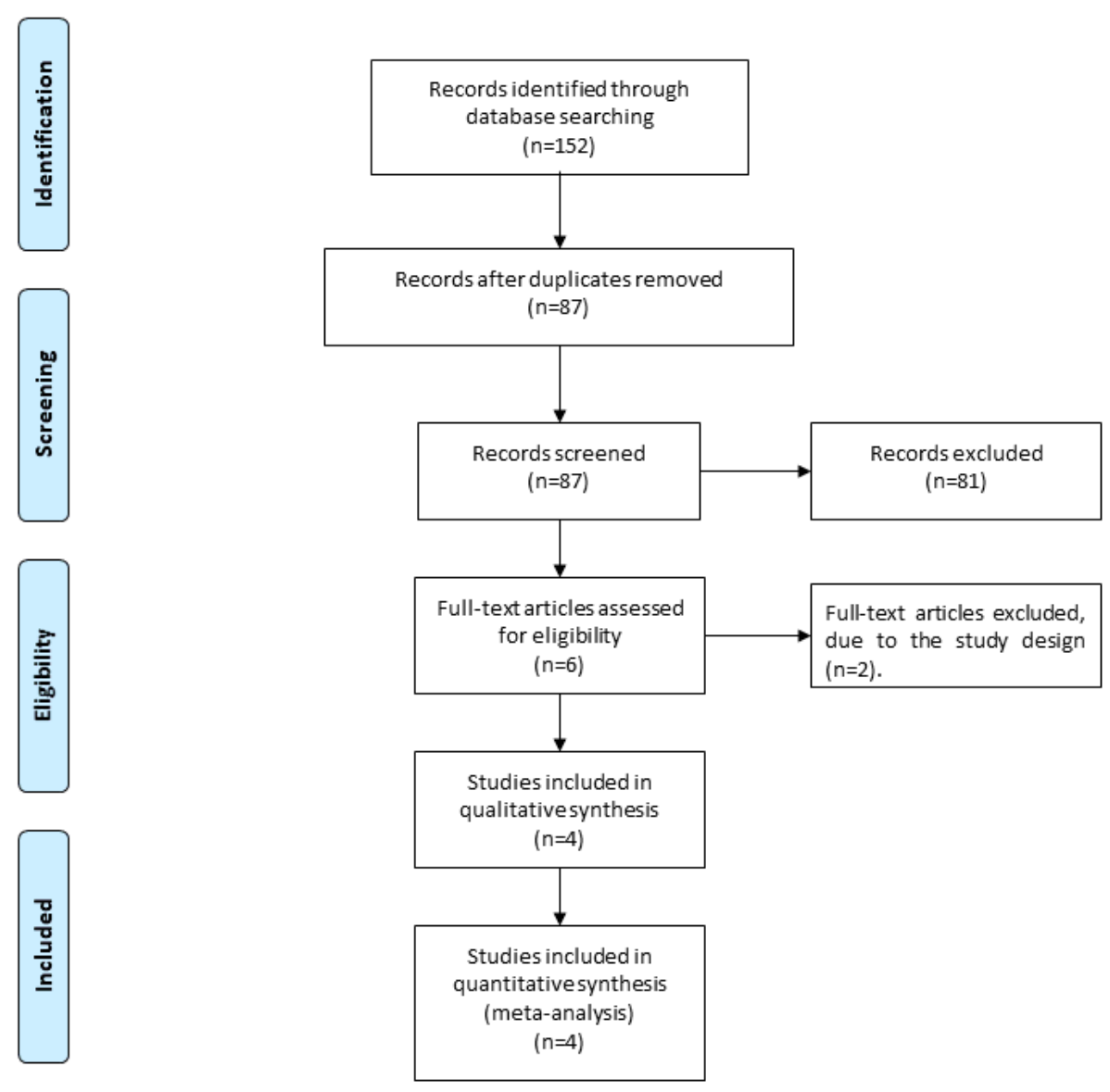

Figure 1

Flow diagram of study searching and selection process.

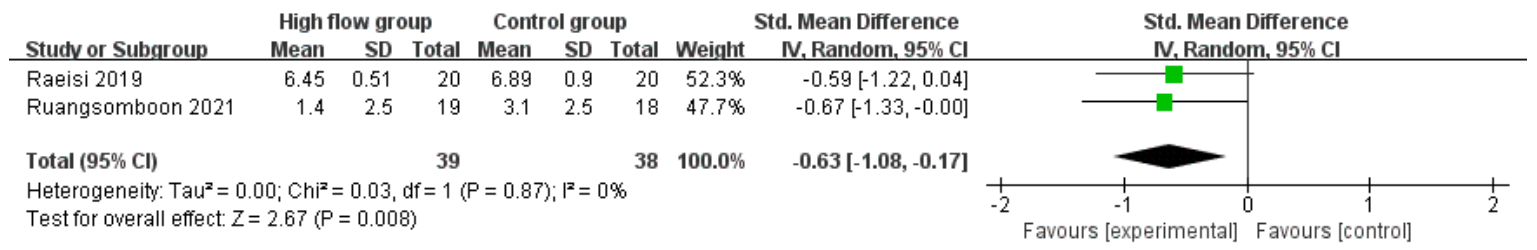

Figure 2

Forest plot for the meta-analysis of dyspnea score.

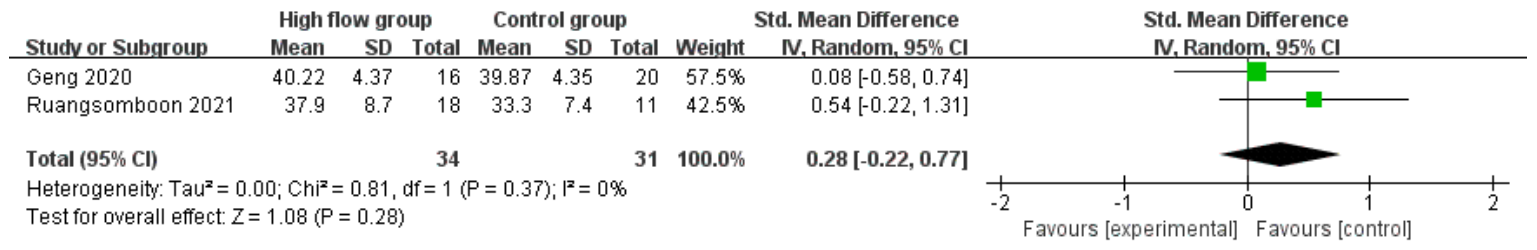

Figure 3

Forest plot for the meta-analysis of $\mathrm{PaCO} 2$.

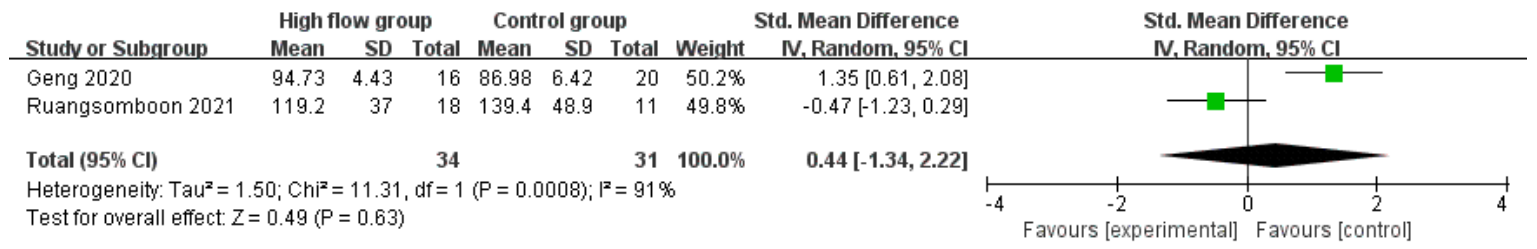


Figure 4

Forest plot for the meta-analysis of $\mathrm{PaO} 2$.

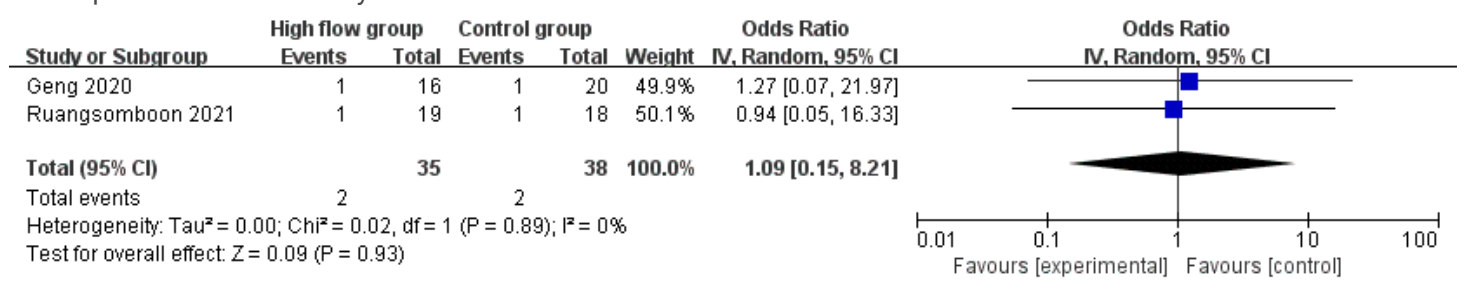

\section{Figure 5}

Forest plot for the meta-analysis of intubation.

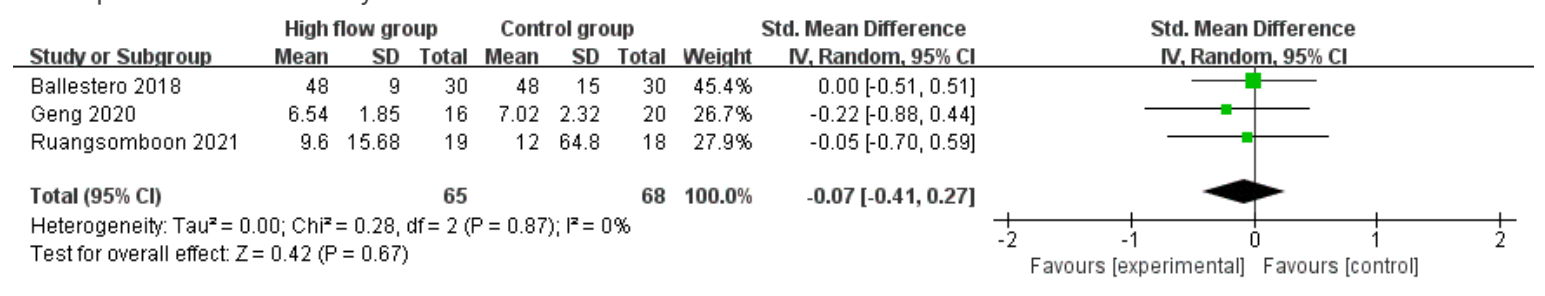

\section{Figure 6}

Forest plot for the meta-analysis of hospital length of stay. 